\title{
Contribution of surface runoff from forested areas to the chemistry of a through-flow lake
}

\author{
Piotr Klimaszyk • Piotr Rzymski • \\ Ryszard Piotrowicz • Tomasz Joniak
}

Received: 2 April 2014/ Accepted: 3 September 2014/Published online: 14 September 2014

(C) The Author(s) 2014. This article is published with open access at Springerlink.com

\begin{abstract}
The role of surface runoff from forested areas in chemical cycling and freshwater ecology is still not completely understood. Changes in total precipitation and increase in heavy rainfalls may, however, in some regions promote the effect of runoff in aquatic environments. In this study, we aimed to investigate the physicochemical properties of the surface runoff occurring within the wooded catchment area of a through-flow lake (Poland, Europe). Samples were collected over a 2-year period from slopes overgrown by the monoculture of Scots pine (Pinus sylvestris) or mixed forest dominated by European beech (Fagus sylvatica) and Scots pine. At the same time, the chemical properties of littoral and pelagic zones were analysed. Waters overflowing both slopes were found to have low $\mathrm{pH}$, high colour and relatively high content of dissolved organic carbon and nutrients. Compared to coniferous site, the runoff from mixed forest was represented by significantly higher concentrations of organic matter, nitrogen, phosphorus and calcium ions. The greatest changes of the studied chemical parameters were noted in runoff occurring during heavy rainfall and snow melting (coniferous slope) or after shedding of leaves (the mixed forest slope). Surface runoff was revealed to be less important source of chemical loads in basins with direct river inflow but for more isolated basins it may be a significant factor affecting water quality.
\end{abstract}

P. Klimaszyk - R. Piotrowicz · T. Joniak

Department of Water Protection, Adam Mickiewicz University, Umultowska 89, 61-614 Poznan, Poland

\section{P. Rzymski ( $\bowtie)$}

Department of Biology and Environmental Protection, Poznan University of Medical Sciences, Rokietnicka 8, 60-806 Poznan, Poland

e-mail: rzymskipiotr@ump.edu.pl
Keywords Surface runoff - Through-flow lake . Nutrients · Organic carbon

\section{Introduction}

The functioning, trophic status and succession of lakes depend mainly on their morphology, catchment area and water balance. The role of surface runoff in the water and chemical cycling is still poorly elucidated. Runoff quantity may vary greatly and it generally depends on rainfall intensity, permeability of soils, slope inclination and the type of overgrowing vegetation (Chang 2012). On the other hand, the chemistry of surface runoff and the dynamics of chemical element washout result from geomorphologic and biological features of catchment area and the degree of human impact (Kim et al. 2014; Klimaszyk et al. 2014). The most significant loads of nutrients are transported to surface waters from agricultural catchments (Vuornenmaa et al. 2002; Liljaniemi et al. 2003; McDowell et al. 2004; Alexakis et al. 2013). This may lead to rapid eutrophication of the aquatic environment (Pote et al. 1999). Urban runoff, in turn, can contain significant concentrations of persistent contaminants such as oil derivates, heavy metals and polycyclic aromatic hydrocarbons, leading to contamination of municipal surface waters (Choe et al. 2002; Azizuddin et al. 2014; Rzymski et al. 2014). In forest ecosystems, it is claimed that the output of nutrients is relatively small when compared to their total amount cycling within the system (Hirobe et al. 2004). However, the elements exported from the wooded catchments may still have considerable impact on the quality of receiving waters (Strobel et al. 2001; Vuornenmaa et al. 2002; Astrom et al. 2004; Park et al. 2011). The role of surface runoff in nutrient cycling is increased with slope 
inclination which can lead to the elution of the upper layers of soil and forest litter directly into the lakes (Sickman et al. 2003).

Several studies have shown that plant coverage can impact the physicochemical properties of surface runoff (Hongve 1999). In some cases surface runoff can be responsible for the humification of lakes resulting from large quantities of organic matter, transported particularly from the coniferous sites (Steinberg 2003; Klimaszyk and Rzymski 2013). The potential role of surface runoff in increasing the trophy of water bodies was also indicated (Klimaszyk and Rzymski 2011). It is likely that different types of forest litter, coniferous, mixed and deciduous, may have a different impact on the chemistry of runoff due to varying quantities of chemical compounds in litter produced by different tree species (Klimaszyk and Rzymski 2011; Hirobe et al. 2004). For example, higher levels of phosphorus and nitrogen are leached from deciduous litter, while coniferous litter is usually richer in organic matter and humic acids (Klimaszyk and Rzymski 2011, 2013).

Under specific meteorological conditions, the impact of surface runoff on the aquatic environment can be increased (Lopez-Vicente et al. 2014). During the heavy rain events, the increase in the volume of surface runoff and concentrations of leached chemicals are observed. The main reason for this phenomenon is the increased erosion of top soil layer (Dils and Heathwaite 1996; Correl et al. 1999). Elevated concentrations of chemical in overland flow can also be observed during snow melting. Freezing and subsequent thawing of forest litter promote the degradation of tissues and cells and increase the elution of nutrients (Renman 1993; Fitzhugh et al. 2001).

The occurrence of heavy rainfall has significantly increased in Central Europe over recent decades (Müller et al. 2009). This phenomenon is also observed in Poland despite the decrease of annual precipitation (Woś 1994). The phenomenon of heavy rain can lead to saturation of the upper part of soils and significant increase of discharge (Steinberg 2003). As a result, higher load of chemicals including nutrients and organic matter, can be transported from the catchment area to lakes and rivers.

The following study was undertaken in order to investigate the overland transfer of chemical substances from wooded areas and to determine the potential impact of forest litter on the physicochemical properties of surface runoff waters. We also aimed to study whether the chemistry of surface runoff can impact the water quality of a through-flow lake. As a model system we have chosen Lake Ostrowiec (Poland, Europe) which is located within the strict protection area of the Drawa National Park (with negligible human pressure). Its direct catchment area is overgrown by coniferous and mixed forests. To evaluate the potential impact of runoff on water quality of the lake, the chemistry of each of its four separated basins was studied. Our work helps to understand the role of runoff in the functioning of the natural mid-forest through-flow water reservoirs.

\section{Materials and methods}

Study area

The study area encompassed Lake Ostrowiec and its catchment area (Drawa National Park, Northern Poland, Europe) at the latitude and longitude of $53^{\circ} 4^{\prime} 39^{\prime \prime} \mathrm{N}$ and $15^{\circ} 57^{\prime} 66^{\prime \prime} \mathrm{E}$, respectively. The lake consists of four basins: B1, B2, B3 and B4 (Fig. 1). Exchange of water between basins is hampered due to the shallow isthmuses. The River Plociczna flows into and out of the northern basin of the lake, and this basin (B1) can be described as a through-flow basin, in contrast to the other lake basins (B3-B4), with no

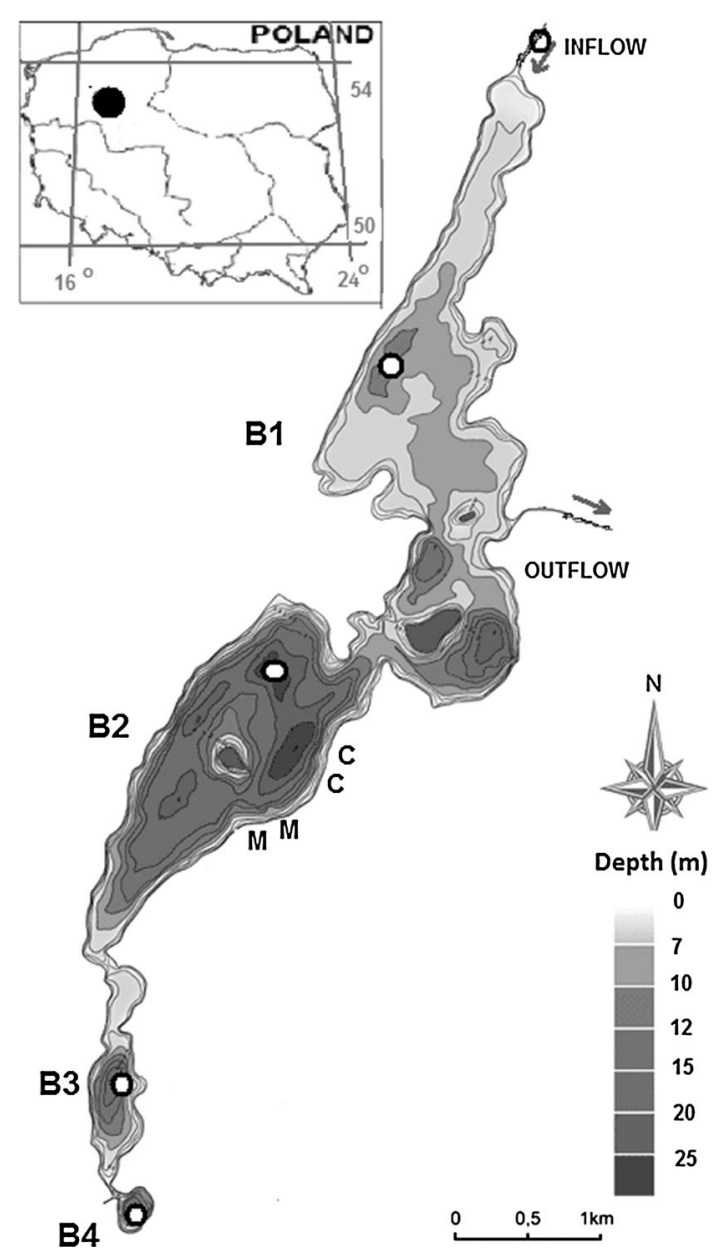

Fig. 1 Bathymetric map of Lake Ostrowiec $(B 1-B 4)$ and location of sampling stations. $C$-coniferous slope overgrown by Scots pine; $M$-slope overgrown by mixed forest (Scots pine and European beech); $O$ —-stations of surface water sampling 
outflow. All basins are stratified and dimictic. The total area of the lake is almost 400 ha and shoreline length is over $22 \mathrm{~km}$ (Table 1). The maximum depth of the lake can be found in $\mathrm{B} 2$ is $(28.5 \mathrm{~m})$, while the other basins are shallower (B1-11 m, B3-17 m, B4-15 m).

The immediate-direct catchment area of Lake Ostrowiec covers about $10 \mathrm{~km}^{2}$, while the area drained by the River Płociczna is almost $202 \mathrm{~km}^{2}$. Over $94 \%$ of the immediate catchment area is covered by forest- 70-year-old Scots Pine (Pinus sylvestris L.) plantation. Because ferruginous soils predominate here (Table 1), the climax habitat is acid beech forest. Since the end of 20th century, the reconstruction of the forests is being implemented by the Drawa National Park services. To reduce pressure from large mammals (roe, deer) and allow the spontaneous renewal of the natural beech forest, squares $(100 \times 100 \mathrm{~m})$ are fenced for 10-15 years.

A characteristic feature of the direct catchment area of Lake Ostrowiec is the significant inclination of slopes (up to $30-40^{\circ}$ near the shoreline) which stimulates water flow and erosion of soils. Mean water inflow from the River Plociczna during the investigated period (January 2009May 2012) was 1.85 (ranging from 1.5 to over $2.2 \mathrm{~m}^{3} \mathrm{~s}^{-1}$ ), while mean outflow from the lake was $1.93 \mathrm{~m}^{3} \mathrm{~s}^{-1}$. Approximately $20 \%$ of rainwater from the direct catchment area is transported to the lake as a surface or subsurface runoff. According to Grześkowiak et al. (2010), over $90 \%$ of water inflow to the lake originates from surface sources: river and surface runoff. Among the surface sources, the river provides almost $85 \%$ of the total volume of water while surface runoff-about $15 \%$. The groundwater does not play a significant role in the water balance of Lake Ostrowiec. In dry years, the lake supplies the aquifer, while in wet years (when annual precipitation exceeds $640 \mathrm{~mm}$ ), there is groundwater inflow into the lake. Despite significant variation in the ratio of groundwater inflow/outflow, the mean water table level is constant (Grzeskowiak et al. 2010).

The mean chemical composition of rainfall during the investigated period (January 2009-May 2012) was as follows: $\mathrm{pH}-6.4$, electrical conductivity-19 $\mu \mathrm{S} \mathrm{cm}^{-1}$, ammonium $\left(\mathrm{NH}_{4}{ }^{+}\right)-0.36 \mathrm{mg} \mathrm{L}^{-1}$, nitrate $\left(\mathrm{NO}_{3}{ }^{-}\right)-$ $0.42 \mathrm{mg} \mathrm{L}^{-1}$, total dissolved nitrogen $(\mathrm{TN})-0.79 \mathrm{mg} \mathrm{L}^{-1}$, organic nitrogen $\left(\mathrm{N}_{\mathrm{org}}\right)-0.3 \mathrm{mg} \mathrm{\textrm {L } ^ { - 1 }}$, total dissolved phosphorus (TP) $-0.1 \mathrm{mg} \mathrm{L}^{-1}$ (data from meteorological station located $3 \mathrm{~km}$ from the lake). Annual precipitation during the investigated period was $607 \mathrm{~mm}$ from March to December 2010 (and over $700 \mathrm{~mm}$ all year), $595 \mathrm{~mm}$ in 2011 and $220 \mathrm{~mm}$ from January to May 2012 (695 $\mathrm{mm}$ all year). Maximum monthly precipitation (defined as a heavy rain period) was noted in the July of 2011 (170 $\mathrm{mm})$. The mean annual multiyear precipitation for the area of Drawa National Park is $610 \mathrm{~mm}$.
Table 1 Characteristic features of Lake Ostrowiec and its catchment area (Piotrowicz et al. 2006)

\begin{tabular}{lll}
\hline Lake area & $\mathrm{Ha}$ & 387.5 \\
Islands area & $\mathrm{ha}$ & 5.8 \\
Length of shoreline & $\mathrm{m}$ & 22,000 \\
Max. depth & $\mathrm{m}$ & 28.5 \\
Mean depth & $\mathrm{m}$ & 9.4 \\
Capacity & $\mathrm{m}^{3}$ & $36,433,100$ \\
Total catchment area & $\mathrm{km}^{2}$ & 211.836 \\
Direct catchment area & ha & $1,044.3$ \\
Catchment use & & \\
Forests & ha $(\%)$ & $986.6(94.47)$ \\
Meadows & ha $(\%)$ & $14.3(1.36)$ \\
Extensive pastures & ha $(\%)$ & $39.7(3.81)$ \\
Waters & ha $(\%)$ & $3.7(0.35)$ \\
Soils & & $770.6(73.78)$ \\
Ferruginous & ha $(\%)$ & $26.3(2.52)$ \\
Podsols & ha $(\%)$ & $15.2(1.46)$ \\
Low structured & ha $(\%)$ & $36.4(3.49)$ \\
Peat & ha $(\%)$ & $11.6(1.11)$ \\
Half-bog & ha $(\%)$ & $4.3(0.41)$ \\
Brown & ha $(\%)$ & $179.9(17.2)$ \\
Unclassified & ha $(\%)$ & \\
\hline
\end{tabular}

Sampling sites and sample collection

Investigations were carried out between January 2009 and May 2012. Surface runoff samplers were installed on two different slopes, adjacent to Lake Ostrowiec. Sampling slopes were similar and representative for all direct catchments in terms of inclination and soil type. Sampling sites were also representative for the dominant forest habitat types (mixed forest and Scots pine monoculture) occurring within the catchment area. Both slopes were steeply inclined (about $40^{\circ}$ ), exposed to the north-east and directly adjacent to the shoreline. Samplers were made of PVC gutters ( $3 \mathrm{~m}$ long and $0.15 \mathrm{~m}$ wide) and sealed plastic collectors buried at the lower end at an angle that prevented the direct inflow of the rainwater. On each slope, two samplers were installed. The first slope (A) was covered by a Scots pine (Pinus sylvestris) monoculture (70-years old), while the second one (B) by 70-year-old Scots pines mixed with dense 20-year-old European beech (Fagus sylvatica) stands (Fig. 1). For this reason, slope A was covered with litter of coniferous origin exclusively, whereas on slope B both deciduous and coniferous litter was present. Gutters were placed under the forest litter and covered with a $0.25 \mathrm{~mm}$ mesh. Care was taken to ensure minimal soil disturbance in the installation of the gutters. On each sampling site, two gutters (in a distance of about $50 \mathrm{~m}$ ) were installed. Runoff samplers were checked after each 
significant precipitation event and during melting of the snowpack. In periods with low precipitation, samplers were checked at least once a month (at the end of the month). During the investigations, monthly number of samples at each station varied from 0 (in winter and months with insignificant precipitation) to 5 .

Water samples from the littoral zone of Lake Ostrowiec were taken $1 \mathrm{~m}$ from the shore, immediately after heavy rainfall or snow melting and during dry periods. Sampling sites were located within close proximity of the slopes where the surface runoff was collected. Water samples from the pelagic zone of lake basins were collected during the summer stagnation. Simultaneously, water samples from the River Płociczna were collected bimonthly during the investigated period. The sampling site was located $80 \mathrm{~m}$ before the river flows into the lake (Fig. 1). Samples of groundwater were collected bimonthly from piezometers installed near the lake adjacent to the surface runoff samplers. During the investigation period, the level of shallow groundwater was stable-no fluctuations larger than $2 \mathrm{~cm}$ were noted. Collected groundwater samples were filtered through a cellulose filter GF-C to remove suspended soil particles. Samples for DOC analysis were filtered through cellulose nitrate filter-pore size $0.45 \mu \mathrm{m}$.

Analyses were conducted in the field or immediately after transportation to the laboratory, if not- samples were frozen at $-20{ }^{\circ} \mathrm{C}$. Daily rainfall data were collected from the meteorological station situated $3 \mathrm{~km}$ from the study site.

\section{Physicochemical analyses}

Electrical conductivity and $\mathrm{pH}$ of water were measured in the field using a YSI 556 Multiparameter Instrument. Water transparency was measured using a Secchi disc. The following parameters were analysed in the laboratory: ammonium ( ${\mathrm{N}-\mathrm{NH}_{4}}^{+}$, using the Nessler method), nitrite $\left(\mathrm{NO}_{2}{ }^{-}\right.$, using the sulphonic acid method), nitrate $\left(\mathrm{N}^{-} \mathrm{NO}_{3}{ }^{-}\right.$, using the sodium salicylate method), $\mathrm{N}_{\text {org }}$ (using the Kjeldahl method), calcium (Ca; using EDTA titration), TP (using the molybdate method after mineralization) and orthophosphate (TRP, using the molybdate method) (APHA 2005). Mineral nitrogen $\left(\mathrm{N}_{\min }\right)$ was expressed as the sum of each investigated mineral $\mathrm{N}$ form. All of these analyses were performed manually. The filtered sample water used as a blank control. Standard curves were plotted for each parameter using standard solutions. Dissolved organic carbon (DOC) was measured using a Shimadzu TOC-5000 A analyzer. Water colour was determined using the platinum-cobalt colour scale (ISO 2211:1973). Chlorophyll-a was determined after extraction in the acetone (ESS Method 150.1, EPA, USA). Chemical oxygen demand (COD) was analysed using the potassium permanganate method (Hermanowicz et al. 1999).

\section{Calculations and statistical analyses}

To evaluate the contribution of surface runoff to the studied lake, Bernardt's formula was used (Czarnecka 1976). According to this formula, it was calculated that $20 \%$ of rainwater from the direct catchment area is transported to the lake as surface runoff. Therefore, $20 \%$ of annual precipitation volume has been considered to represent surface runoff.

To estimate the volume of water provided to the lake by the River Płociczna, water flow was measured bimonthly using Electromagnetic Water Flow Meter (Valeport, United Kingdom). At the station located $80 \mathrm{~m}$ from the river mouth, eight hydrometrical verticals in the transect from the shore were chosen in order to measure the flow velocity. Depending on each vertical, the velocity was made at several depths-according to Bajkiewicz-Grabowska and Mikulski (2010). The total river water discharge was calculated as a sum of flows for areas between verticals.

The loads of $\mathrm{N}$ and $\mathrm{P}$ inflowing into the lake with river were calculated according to the annual volume of the inflowing water and mean concentration of TN and TP in the River Płociczna water. The loads of nutrients delivered to the lake with surface runoff were calculated as a sum of $\mathrm{N}$ and $\mathrm{P}$ discharge from coniferous and mixed forest catchment. The load of $\mathrm{N}$ and $\mathrm{P}$ from each type of catchment was calculated as a volume of surface runoff from sub-catchment and mean concentration of TN and TP in the surface runoff water.

The trophic state (TSI) of the basins of Lake Ostrowiec was calculated according to Carlson (1977) which is based on TP and chlorophyll-a concentrations, and Secchi disc visibility.

Statistical analyses were determined using Statistica 8.0 (StatSoft, USA). Gaussian distribution was evaluated with the Shapiro-Wilk's test and because the data did meet this assumption, evaluation of differences between the studied sites was assessed using the T-Student test, while correlations between total precipitation and physicochemical parameters were defined using the Pearson coefficient. A $p$ value of $<0.05$ was considered as statistically significant.

\section{Results}

Surface runoff water characteristics

Surface runoff within the study site contained a relatively high content of DOC (mean \pm SD $61.04 \pm 18.12 \mathrm{mg} \mathrm{L}^{-1}$ ) 
Table 2 Physical and chemical properties of water inflowing into the Lake Ostrowiec

\begin{tabular}{|c|c|c|c|c|c|}
\hline & & \multicolumn{2}{|c|}{ Surface runoff $(\mathrm{n}=22)$} & \multirow{2}{*}{$\begin{array}{l}\text { Groundwater } \\
(\mathrm{n}=12)\end{array}$} & \multirow{2}{*}{$\begin{array}{l}\text { River inflow } \\
(\mathrm{n}=12)\end{array}$} \\
\hline & & Coniferous forest & Mixed forest & & \\
\hline Color & $\operatorname{mg~Pt~L~}{ }^{-1}$ & $237.2 \pm 46.32$ & $247.9 \pm 52.8$ & $66.6 \pm 22.6$ & $33 \pm 9.62$ \\
\hline COD & $\mathrm{mg} \mathrm{O}_{2} \mathrm{~L}^{-1}$ & $104.7 \pm 22.01$ & $137.4 \pm 33.98$ & $78.2 \pm 2.5$ & $8.4 \pm 4.12$ \\
\hline $\mathrm{Ca}$ & $\mathrm{mg} \mathrm{Ca} \mathrm{L}{ }^{-1}$ & $4.57 \pm 0.63$ & $6.44 \pm 1.59$ & $12.8 \pm 4.11$ & $63.4 \pm 9.11$ \\
\hline TRP & $\mathrm{mg} \mathrm{P} \mathrm{L}{ }^{-1}$ & $0.163 \pm 0.09$ & $0.29 \pm 0.13$ & $0.09 \pm 0.01$ & $0.03 \pm 0.01$ \\
\hline TP & $\operatorname{mg~P~L}{ }^{-1}$ & $0.31 \pm 0.13$ & $0.42 \pm 0.15$ & $0.16 \pm 0.04$ & $0.1 \pm 0.07$ \\
\hline $\mathrm{N}$ org & $\operatorname{mg~N~L}{ }^{-1}$ & $2.34 \pm 1.14$ & $2.81 \pm 1.32$ & $1.38 \pm 0.62$ & $1.1 \pm 0.33$ \\
\hline N-NH4 & $\operatorname{mg~N~L}{ }^{-1}$ & $2.81 \pm 0.74$ & $2.38 \pm 0.78$ & $1.58 \pm 0.52$ & $0.3 \pm 0.2$ \\
\hline $\mathrm{N}-\mathrm{NO}_{3}$ & $\operatorname{mg~N~L}{ }^{-1}$ & $0.82 \pm 0.53$ & $0.94 \pm 0.46$ & $1.17 \pm 0.55$ & $0.92 \pm 0.25$ \\
\hline $\mathrm{N}-\mathrm{NO}_{2}$ & $\mathrm{mg} \mathrm{N} \mathrm{L}^{-1}$ & $0.005 \pm 0.01$ & $0.002 \pm 0.003$ & $0.002 \pm 0.004$ & $0.002 \pm 0.002$ \\
\hline DOC & $\operatorname{mg~C~L}{ }^{-1}$ & $55.8 \pm 15.9$ & $66.6 \pm 19.3$ & $43.2 \pm 6.1$ & $13.4 \pm 4.2$ \\
\hline $\mathrm{pH}$ & - & $3.8-5.5$ & $4.9-6.6$ & $5.2-6.7$ & $7.1-8.2$ \\
\hline el. cond. & $\mu \mathrm{Sm} \mathrm{cm}{ }^{-1}$ & $121.6 \pm 52.1$ & $151.2 \pm 74.92$ & $281.5 \pm 36.2$ & $325 \pm 45.2$ \\
\hline
\end{tabular}

and was characterized by intense brown colour (222.4 $\left.\pm 51.6 \mathrm{mg} \mathrm{L}^{-1}\right)$. Moreover, high concentrations of $\mathrm{TN}$ and TP were found; mean $6( \pm 2.01) \mathrm{mg} \mathrm{L}^{-1}$ and 0.4 $( \pm 0.22) \mathrm{mg} \mathrm{L}^{-1}$, respectively. Runoff waters were also characterized by low acidity ( $\mathrm{pH}<6.0$ in $90 \%$ samples) and electrical conductivity with a mean $128( \pm 37.2) \mu \mathrm{S}$ $\mathrm{cm}^{-1}$.

Differences in the chemistry of surface runoff were found between coniferous and mixed forest site (Table 2). Waters overflowing slope A (Scots pine) demonstrated higher $\mathrm{N}-\mathrm{NH}_{4}$ content and lower $\mathrm{pH}$. On the other hand, runoff occurring on slope B (Scots pine + European beech) was found to contain larger concentrations of dissolved organic matter. During the investigated period, DOC concentrations on slope B were higher by $20 \%$ compared to slope A, whereas COD contents were higher by $30 \%$. Moreover, water had a more intense brown colour. Apart from organic matter, surface runoff from the mixed forest contained significantly higher concentrations of nutrients. Compared to slope A, mean concentrations of TP and TRP were higher by 50 and $70 \%$, respectively. TN was also higher (by $10 \%$ ) with a prevalence of $\mathrm{N}_{\text {org }}$ and $\mathrm{N}-\mathrm{NO}_{3}$. Significant differences were also noted for electrical conductivity and $\mathrm{Ca}$ concentrations, with runoff from slope B having higher values of both parameters.

The concentrations of the studied parameters were greatly affected by precipitation. The highest concentration of chemical compounds was found during heavy rainfall and snow melting (Fig. 3). On slope A, significant positive correlations with total precipitation (sum of precipitation from sampling to sampling) were found for COD $(\mathrm{r}=0.76), \quad$ DOC $\quad(r=0.77) \quad$ TP $\quad(r=0.67), \quad \mathrm{N}_{\text {org }}$ $(\mathrm{r}=0.75), \quad \mathrm{N}_{-} \mathrm{NH}_{4} \quad(\mathrm{r}=0.55)$ and $\mathrm{N}^{-N_{3}} \quad(\mathrm{r}=0.79)$. Generally, the highest concentrations of the studied parameters were noted during heavy rainfall in summer and autumn, as well as snow melting. In the case of TP, the highest concentrations (from 0.5 to over $0.7 \mathrm{mg} \mathrm{L}^{-1}$ ) were found in July, August 2010 and July 2011 (Fig. 2) with monthly sum of precipitation exceeding $100 \mathrm{~mm}$ and heavy rainfall events (over $40 \mathrm{~mm}$ during $24 \mathrm{~h}$ ). During these months, the highest concentrations of $\mathrm{N}_{\text {org }}$ and $\mathrm{N}_{\text {min }}$ (over $5 \mathrm{mg} \mathrm{L}^{-1}$ ) and DOC (Fig. 2) were reported. The highest concentration of TRP in surface runoff was observed after heavy rain in July 2011 (over $0.3 \mathrm{mg} \mathrm{L}^{-1}$ ), although increased values were also found during freezingthawing periods (Fig. 2). The concentration of $\mathrm{Ca}$ in surface runoff on slope A was stable throughout the investigated period. On slope $\mathrm{B}$, precipitation was found to be positively correlated only with $\mathrm{N}_{\text {org }}(\mathrm{r}=0.54)$. Here, the highest concentrations of TP, TRP, $\mathrm{N}_{\text {min }}$ and $\mathrm{Ca}$ were observed after the period of beech leaves shedding. The maximal values were noted every year from February to April (Fig. 2) during thawing and melting of the snowpack. The concentrations of these elements in surface runoff during the period of most intensive leaves shedding (October-November) were relatively low-probably due to small total month precipitation rates (below $30 \mathrm{~mm}$ ). The highest concentrations of DOC and $\mathrm{N}_{\text {org }}$ in surface runoff at slope $\mathrm{B}$ were observed both in the periods of snow melting and heavy rains (Fig. 2).

Heavy rainfall and subsequent intensive runoff had an effect on the physicochemical conditions of water of the littoral zone of the studied lake. During these periods, water in the littoral zone was characterized by lower $\mathrm{pH}$ (5.8 vs 7.8), compared to pelagic zone; it had a more intensive colour (mean 44 vs $22 \mathrm{mg} \mathrm{L}^{-1}$ ), lower Ca concentration (mean 26 vs $48 \mathrm{mg} \mathrm{L}^{-1}$ ), higher TRP (mean 0.09 vs. $0.02 \mathrm{mg} \mathrm{L}^{-1}$ ), TN (mean 2.3 vs. $1.13 \mathrm{mg} \mathrm{L}^{-1}$ ) and DOC (mean 36 vs. $14 \mathrm{mg} \mathrm{L}^{-1}$ ) contents. It was impossible to confirm this trend during intensive snowmelt because the lake was ice-covered. In periods with no heavy rainfall, no significant differences in the studied physicochemical 

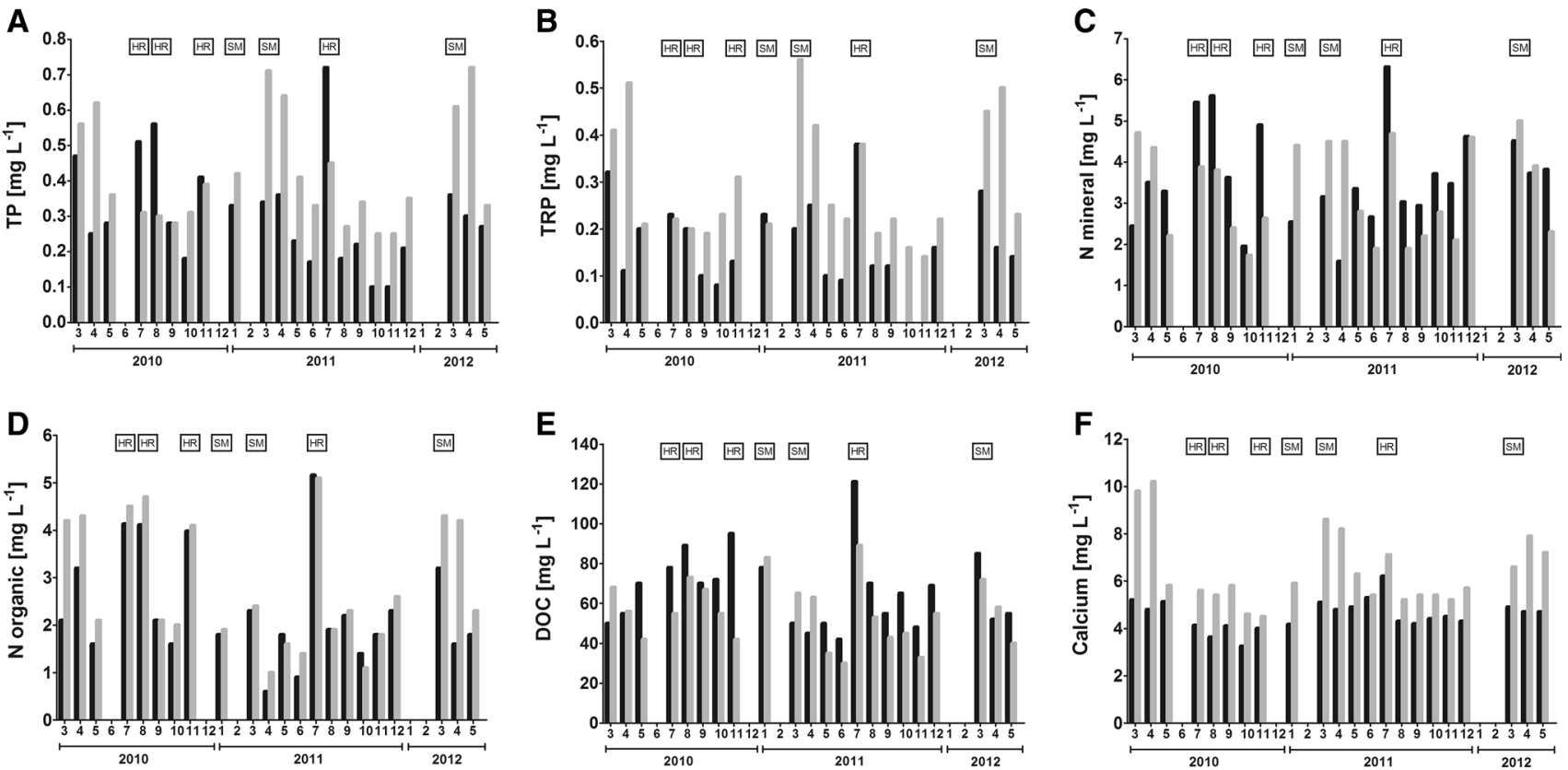

Fig. 2 Monthly variations in total phosphorus (TP), total reactive phosphorus (TRP), mineral and organic $\mathrm{N}$, dissolved organic carbon (DOC) and calcium in the surface runoff from the catchment area of

Lake Ostrowiec. Black blocks—coniferous area; grey blocks-mixed forest area; $H R$ - heavy rainfall events; $S M$ - snow melting events

parameters were found between littoral and open water zones.

Chemistry of river inflow and groundwater

Water inflowing into Lake Ostrowiec from the River Plociczna contained relatively high concentrations of $\mathrm{Ca}$ (Table 2). The maximal value noted during the investigated period reached over $80 \mathrm{mg} \mathrm{L}^{-1}$. The concentrations of nutrients were significant with over $2 \mathrm{mg} \mathrm{L}^{-1}$ of TN and $0.1 \mathrm{mg} \mathrm{L}^{-1}$ of TP. However, concentrations of organic matter were relatively low (Table 3 ). Riverine water contained a moderate amount of soluble mineral salts-the value of electrical conductivity fluctuated in the range of $311-425 \mu \mathrm{S} \mathrm{cm}^{-1}$.

The properties of shallow ground water were different compared to the river inflow. The water was slightly brown and the concentrations of organic matter expressed as a COD or DOC were significant (Table 2) The concentrations of nutrients were high with over $4 \mathrm{mg} \mathrm{L}^{-1}$ of TN and almost $0.2 \mathrm{mg} \mathrm{L}^{-1}$ of TP. The amount of $\mathrm{Ca}$ in groundwater was three times lower compared to water inflowing with the river (Table 2).

\section{Chemistry of lake basins}

Significant differences in the chemistry of water were found between the studied basins. The northern basin (B1) was characterized by the highest values of nutrients and chlorophyll-a and the lowest water transparency and oxygen conditions (with total oxygen depletion from a depth of $6 \mathrm{~m}$ onwards). The concentration of total P in B2-B4 was threefold lower compared to B1. Significant differences between B1 and B2-B4 were also found for electrical conductivity and concentrations of all investigated $\mathrm{N}$ forms (Table 3). Similarly to B1, oxygen depletion in the deep water zone of B2-B4 was observed, although oxycline started much deeper and, despite significant maximal depth, bottom water was still saturated with low concentrations of oxygen.

The main factor responsible for the differences in physicochemical properties of water is a water regime. The direct sub-catchment of B1 has the largest surface (Table 3) and the highest share of spatial sources in nutrient loading. Furthermore, the inflow and outflow of the river are located at $\mathrm{B} 1$. The inflowing River Płociczna is responsible for over $90 \%$ of total $\mathrm{N}$ and nearly $90 \%$ of total P loads (Table 4). Moreover, the river provides relatively more $\mathrm{N}$ than $\mathrm{P}$ compared to other sources. The N:P ratio for the river was above 19 , for runoff-16 and for precipitation-10 (Table 4). The morphology of the studied lake (shallow narrowing) largely limits the exchange of water between basins. Therefore, the main sources of nutrient loading for B2-B4 include spatial sources: precipitation and surface runoff from the direct catchment. For these basins, larger loads (75\% of total $\mathrm{N}$ and $66 \%$ of total P) are supplied with surface runoff (Table 4). Differences in hydrology and chemical properties of water 

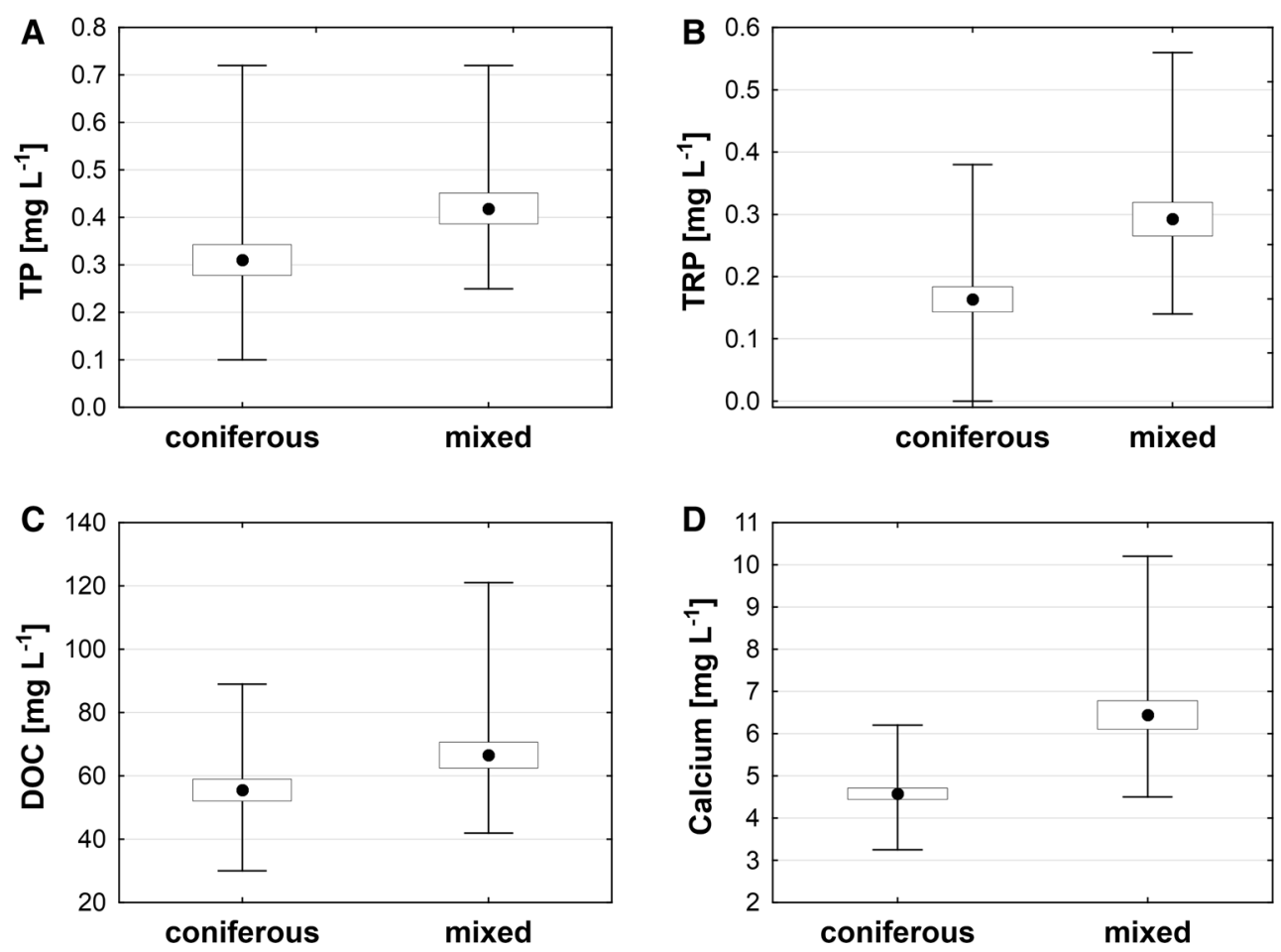

Fig. 3 Comparison of the concentration of the total phosphorus (a), orthophosphate (b), dissolved organic carbon (DOC) (c) and calcium (d) in surface runoff from the Lake Ostrowiec catchment, (central point-mean; box-SD; whiskers-min/max). T-student test $p<0.05$

between basins were reflected in their trophic status. According to TSI, through-flow basin B1 was found to be eutrophic, while other basins were mesotrophic or mesoeutrophic (Table 3).

\section{Discussion}

Our investigations demonstrate that the most important factor affecting the water quality of Lake Ostrowiec is its through-flow character. The inflowing River Płociczna plays a major role in the water balance and chemical loading to the lake. Due to the differentiation of basins, the impact of the river is manifested predominantly in the northern basin (B1) where chemical loads are being imported. This results in the highest concentration of nutrients, decreased water transparency, oxygen depletion in deep water layers and generally, eutrophic state of the basin. The River Płociczna also affects the chemistry of other basins, which is reflected, e.g., in high Ca concentrations, similar to those found in the river. It is worth noting that neighbouring non-through-flow lakes, in which overland flow predominates the water balance, are characterized by fourfold lower Ca concentrations (Piotrowicz et al. 2006). The electrical conductivity of Lake Ostrowiec and the River Płociczna is comparable while in the neighbouring lakes it is decreased threefold (Piotrowicz et al. 2006). As demonstrated in other studies, rivers can significantly affect the chemistry of through-flow lakes and contribute to their eutrophication (Ramm and Scheps 1997; Hilbricht-Ilkowska 1999; Bajkiewicz-Grabowska and Zdanowski 2006). However, in spite of this, surface runoff may play an important role in the functioning of the studied lake, particularly for the non-through-flow basins (B2-B4). This is also supported by the low contribution of groundwater in the water balance of Lake Ostrowiec (Grześkowiak et al. 2010). The high inclination of the slopes surrounding the lake promotes the formation of surface runoff and increases erosion (Rorke 2000), therefore, runoff can transport large volumes of water enriched with chemical compounds leached from the forest litter.

Surface runoff is a short termed and episodic event and its chemical properties are thus difficult to study in the natural environment. Nevertheless, its potential impact on the chemistry of aquatic environments cannot be marginalized (McDowell et al. 2004). It has already been found that in nonthrough-flow water bodies, surface runoff can contribute to the processes of eutrophication and humification (Klimaszyk and Rzymski 2011, 2013). Runoff from forested areas is usually characterized by a high concentration of DOC (Klimaszyk and Joniak 2011). The DOC content found in our study was similar to that observed in waters of transitional and raised bogs (Elder et al. 2000). Inflows of water characterized by such a high DOC content are considered to be one of the main factors contributing to the process of lake humification. It was indicated that 


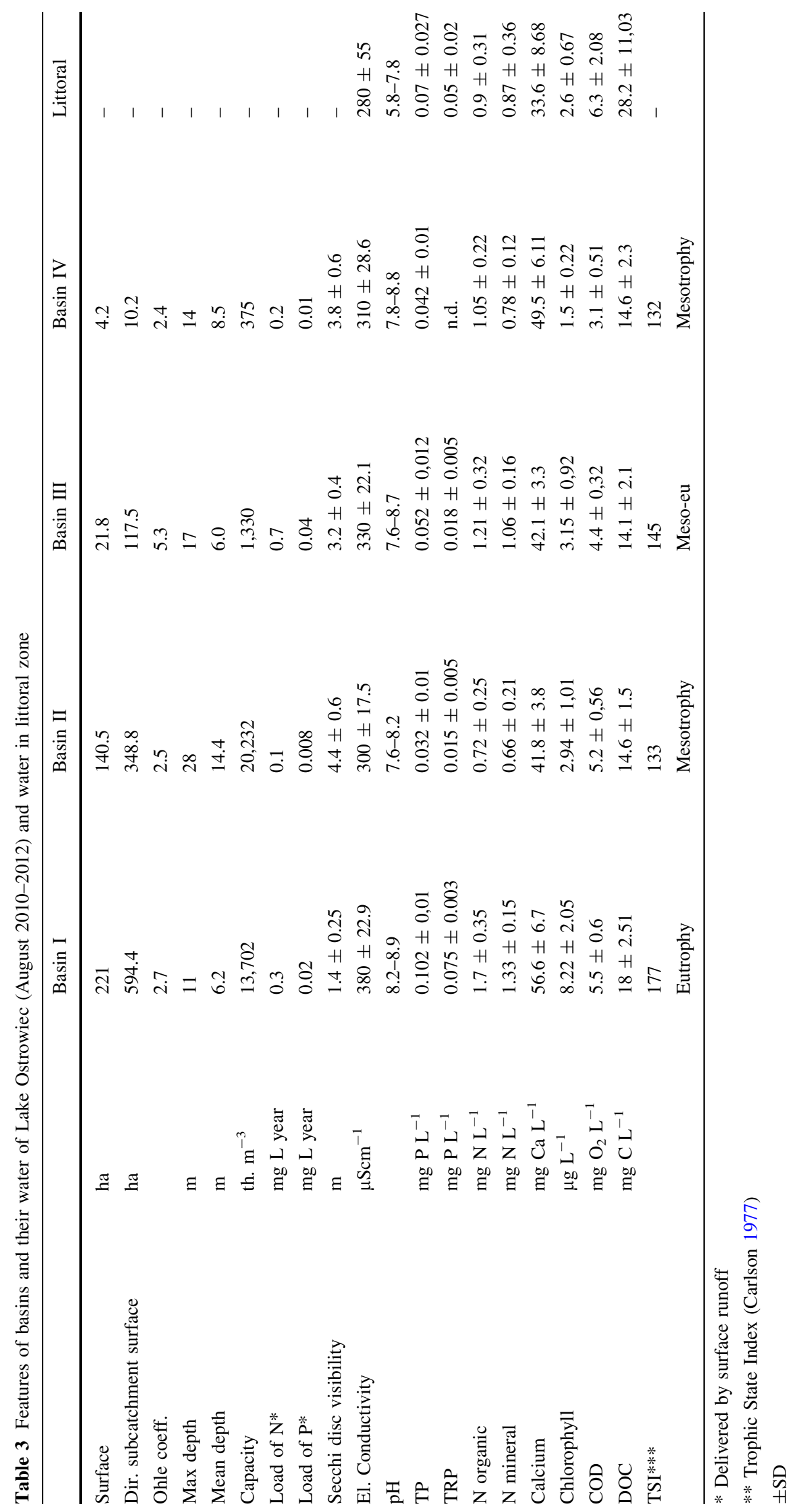


Table 4 Loads of nitrogen $(\mathrm{N})$ and phosphorus $(\mathrm{P})$ inflowing into the Lake Ostrowiec from the external sources

\begin{tabular}{lccllc}
\hline Source & $\mathrm{N}$ & & & $\mathrm{P}$ \\
\cline { 2 - 3 } \cline { 5 - 6 } & $\mathrm{kg} 10^{3}$ year $^{-1}$ & $\%$ & & $\mathrm{~kg}^{3} 0^{3}$ year $^{-1}$ & $\%$ \\
\hline Surface runoff & 8.6 & 6.4 & 0.53 & 7.3 \\
Precipitation & 2.74 & 2.1 & & 0.27 & 3.7 \\
Płociczna River & 123.77 & 91.5 & & 6.45 & 89 \\
Total & $\mathrm{N} \mathrm{tot.}=135.13 \mathrm{~kg} 10^{3}$ & & P tot. $=7.25 \mathrm{~kg}$ & $10^{3}$ \\
& year $^{-1}$ & & & year & \\
\hline
\end{tabular}

runoff from coniferous areas contains higher DOC concentrations than this occurring within the deciduous sites (Kortelainen 1999; Strobel et al. 2001). These findings were further confirmed in experiments demonstrating that compared to beech (Klimaszyk and Rzymski 2011) and birch (Klimaszyk and Rzymski 2013) litter, higher amount of DOC is leached from pine litter. Despite it, deciduous forest can still be a source of significant levels of DOC (Hongve 1999). As found in the present study, compared to the pine monoculture, runoff occurring within the mixed forest was characterized by higher DOC levels. This is most likely due to the production of additional portion of detritus by beech, a source of DOC. Our investigation also revealed that DOC levels in surface runoff depend on precipitation. At both studied sites, the highest DOC content was found after heavy rainfall events and during snow melting. This is consistent with other studies (Cronan and Aiken 1985; Hope et al. 1994; Klimaszyk and Rzymski 2013). Young beech stands at sampling station shed their leaves gradually from November to March (the most intensively from November to December). Freeze-thawing and generally humid conditions accelerate the decomposition of forest litter and release of DOC during snow melting (Renman 1993; Klimaszyk and Rzymski 2011).

Following rainfall, littoral waters of the studied lake were found to have lower $\mathrm{pH}$, increased colour and DOC concentration. The chemistry of the pelagic zone, not affected by runoff, clearly indicates the oligohumic character of Lake Ostrowiec. It is thus possible that humic substances are photodegraded and included in the microbial loop (Anesio et al. 2005).

Compared to groundwater and river inflow, surface runoff was characterized by significantly higher concentrations of nutrients. These differences were expressed several folds indicating that runoff may be an important factor influencing the productivity of the studied lake. In addition, the relatively low $\mathrm{N}: \mathrm{P}$ ratio in runoff (in comparison to other sources) shows that it is an important source of $\mathrm{P}$. The observed concentrations of $\mathrm{N}$ and $\mathrm{P}$ were comparable to those already found in sloping forested catchment areas (Klimaszyk and Rzymski 2011, 2013) but lower than those found for agricultural lands (Beman et al. 2005). As demonstrated experimentally, leaching of nutrients may vary depending on the type of forest litter ( $\mathrm{Zi}$ eliński et al. 1999). Our field study shows that mixed forests make a larger contribution to the mobilization and transfer of $\mathrm{N}$ and $\mathrm{P}$ than coniferous areas. Depending on the nutrient availability in soils, deciduous species withdraw $\mathrm{N}$ and $\mathrm{P}$ content before leaf senescence, but the magnitude of this process appears to be lower than it is for coniferous species (Pensa et al. 2007; Schulze et al. 2009). This was also found for the European beech (Vesterdal 1999), species overgrowing the investigated area of the mixed forest. Here we also demonstrated that mixed forest has a higher impact on leaching of $\mathrm{Ca}$. It was previously demonstrated experimentally that European beech litter is richer in $\mathrm{Ca}$ than the litter of Scots pine (Reich et al. 2005) which is now confirmed in our field investigations.

The runoff flow rate, which is correlated with precipitation, is indicated as a main factor affecting the washing out of nutrients (Lewis et al. 1999; Sickman et al. 2003; Shigaki et al. 2007; Klimaszyk and Rzymski 2011) and organic matter (Cronan and Aiken 1985; Hongve 1999; Klimaszyk 2006). Out of all the investigated chemical parameters, the highest concentrations were observed in runoff collected after heavy rainfall and during intensive snowmelt. Increased values noted in winter and early spring may be unexpected as the rate of forest litter decomposition is decreased in lower temperatures (Sulkava and Huhta 2003). On the other hand, freezing-thawing periods may promote the degradation of organic matter (Renman 1993) and at the same time increase the elution of nutrients from soils (Fitzhugh et al. 2001). It should also be noted that for the mixed forest, the highest concentrations of chemical elements were noted in surface runoff in late autumn and the following period of falling leaves. As found experimentally, litter of beech origin can rapidly release organic matter and other chemical compounds (Klimaszyk and Rzymski 2011). As autumn in temperate climates is generally characterized by rainfall, it may have the largest impact on chemical leaching from forest litter and its subsequent transport with runoff to aquatic environments.

The monocultures of Scots pine overgrowing the catchment area of Lake Ostrowiec are gradually being replaced by climax forest with beech. According to the Protection Plan for the Drawa National Park in the next 50 years, the whole catchment should be covered with climax ecosystems with the prevalence of beech forest. This will result in a change in the physical and chemical properties of runoff waters and will increase the loads of nutrients inflowing into the lake and potentially promote its eutrophication. 


\section{Conclusions}

Our study demonstrated that surface runoff significantly affected the chemistry of a through-flow, mid-forest lake. Litter from the mixed forest released higher concentrations of nutrients and organic matter than coniferous areas. The highest leaching was observed after heavy rainfall and during snow-melting. In the case of the mixed forest, the highest chemical enrichments of runoff waters were found after autumn leaf shedding, indicating a high contribution of European beech in the $\mathrm{N}$ and $\mathrm{P}$ cycle. Gradual replacements of Scots pine monocultures with beech, which can be also observed within the catchment area of Lake Ostrowiec, will likely increase nutrient loading to the mid-forest surface freshwaters.

Acknowledgments Investigations were supported by the Polish Ministry of Education Grant No. NN305 100435.

Open Access This article is distributed under the terms of the Creative Commons Attribution License which permits any use, distribution, and reproduction in any medium, provided the original author(s) and the source are credited.

\section{References}

Alexakis D, Kagalou I, Tsakiris G (2013) Assessment of pressures and impacts on surface water bodies of the Mediterranean. Case study: Pamvotis Lake, Greece. Environ Earth Sci 70:687-698

Anesio AM, Granelli W, Aiken GR, Kieber DJ, Mopper K (2005) Effect of humic substance photodegradation on bacterial growth and respiration in lake water. Appl Environ Biol 71:6267-6275

APHA (2005) Standard Methods for Water and Wastewater Analysis, New York

Astrom M, Aaltonen EK, Koivusaari J (2004) Changes in leaching patterns of nitrogen and phosphorus after artificial drainage of a boreal forest - a paired catchment study in Lappajarvi, Western Finland. Boreal Env Res 10:67-78

Azizuddin AD, Ali NAM, Tay KS, Abas MRB, Simoneit BRT (2014) Characterization and sources of extractable organic matter from sediment cores of an urban lake (Tasik Perdana), Kuala Lumpur, Malaysia. Environ Earth Sci 71:4363-4377

Bajkiewicz-Grabowska E, Mikulski Z (2010) Principles of hydrology. PWN, Warsaw (in Polish)

Bajkiewicz-Grabowska E, Zdanowski W (2006) Phosphorus retention in lake sections of Struga Siedmiu Jezior. Limnol Rev $6: 5-12$

Beman MJ, Arrigo KR, Matson PA (2005) Agricultural runoff fuels large phytoplankton blooms in vulnerable areas of the ocean. Nature 434:211-214

Carlson RE (1977) A trophic state index for lakes. Limnol Oceanogr 22:361-369

Chang M (2012) Forest hydrology: an introduction to water and forests. CRC Press, Boca Raton

Choe JE, Bang KW, Lee JH (2002) Characterization of surface runoff in urban areas. Water Sci Technol 45:249-254

Correl DL, Jordan TI, Weller DE (1999) Transport of nitrogen and phosphorus from Rhode River watershed during storm events. Water Resour Res 35:2513-2521
Cronan CR, Aiken GR (1985) Chemistry and transport of soluble humic substances in forested watersheds of Adirondack Park, New York. Geochi Cosmochim Acta 49:1697-1705

Czarnecka H (1976) Attempt to outflow calculations in small uncontrolled drainage basins on the basis of the soil cover. Gosp Wod 8-9:225-230 (in Polish)

Dils RM, Heathwaite AL (1996) Phosphorus fractionation in hillslope hydrological pathways contributing to agricultural runoff. In: Anderson M, Bookes S (eds) Advances in hillslope processes. John Wiley \& Sons Ltd, Chichester, pp 229-252

Elder JF, Rybicki NB, Carter V, Weintraub V (2000) Sources and yelds of dissolved carbon in North Western Wisconsin stream catchments with different amount of peatlands. Wetlands 20:121-135

Fitzhugh RD, Driscoll CT, Groffman PM, Tierney GL, Fahey TJ, Hardy JP (2001) Effects of soil freezing disturbance on soil solution nitrogen, phosphorus, and carbon chemistry in a northern hardwood ecosystem. Biogeochemistry 56:215-238

Grześkowiak A, Jańczak J, Sziwa R (2010) Hydrology and water quality of Lake Ostrowiec in the Drawa National Park. Drawa Natural Park, Poland

Hermanowicz W, Dojlido J, Dożańska W, Koziorowski B, Zerbe J (1999) The physical-chemical analyses of water and wastewater. Arkady Press, Warsaw

Hilbricht-Ilkowska A (1999) Shallow lakes in lowland river systems: role in transport and transformations of nutrients and in biological diversity. Hydrobiologia 408(409):348-359

Hirobe M, Sabang J, Bhatta BK, Takeda H (2004) Leaf-litter decomposition of 15 tree species in a lowland tropical rain forest in Sarawak: dynamics of carbon, nutrients, and organic constituents. J Res 9:347-354

Hongve D (1999) Production of dissolved organic carbon in forested catchments. J Hydrol 224:91-99

Hope D, Billet MF, Cresser MS (1994) A review of the export of carbon in river waters: fluxes and processes. Environ Pollut 84:301-324

Kim S-W, Park J-S, Kim D, Oh J-M (2014) Runoff characteristics of non-point pollutants caused by different land uses and a spatial overlay analysis with spatial distribution of industrial cluste: a case study of the lake Sihwa watershed. Environ Earth Sci 71:483-496

Klimaszyk P (2006) Peatbog - humic water complex in forest landscape: factors determining its functioning. Pol $\mathrm{J}$ Environ Stud 15:384-388

Klimaszyk P, Joniak T (2011) Impact of black cormorant on the transport of dissolved organic carbon from the catchment area to the lakes. Pol J Soil Sci 44:161-166

Klimaszyk P, Piotrowicz R, Rzymski P (2014) Changes in the ecosystem of shallow softwater lake induced by the Great Cormorant roosting colony. J Limnol. doi:10.4081/jlimnol.2014. 994

Klimaszyk P, Rzymski P (2011) Surface runoff as a factor determining trophic state of midforest lake (Piaseczno Małe, North Poland). Pol J Environ Stud 20:1203-1210

Klimaszyk P, Rzymski P (2013) Catchment vegetation can trigger lake dystrophy through changes in runoff water quality. Ann Limnol - Int J Limnol 41:191-197

Kortelainen P (1999) Source of aquatic organic carbon. In: Keskitalo J, Eloranta P (eds) Limnology of humic waters. Backhuys Publishers, Leiden, pp 43-57

Lewis WM, Melack JM, Mcdowell WH, Mcclain M, Richney JE (1999) Nitrogen yields from undisturbed watersheds in the America. Biogeochemistry 46:149-162

Liljaniemi P, Vuori KM, Tossavainen T, Kotanen J, Haapanen M, Lepisto A (2003) Effectiveness of constructed overland flow 
areas in decreasing diffuse pollution from forest drainages. Environ Manage 32:602-613

Lopez-Vicente M, Navas A, Gaspar L, Machin J (2014) Impact of the new common agricultural policy of the EU on the runoff production and soil moisture content in a Mediterranean agricultural system. Environ Earth Sci 71:4281-4296

McDowell RW, Biggs BJF, Sharpley AN, Nguyen L (2004) Connecting phosphorus loss from agricultural landscapes to surface water quality. Chem Ecol 20:1-40

Müller M, Kašpar M, Matschullat J (2009) Heavy rains and extreme rainfall-runoff events in Central Europe from 1951 to 2002. Nat Hazard Earth Syst Sci 9:441-450

Park S-R, Lee H-J, Lee S-W, Hwang S-J, Byeon M-S, Joo G-J, Jeong K-S, Kong D-S, Kim M-C (2011) Relationships between land use and multi-dimensional characteristics of streams and rivers at two different scales. Ann Limnol - Int J Limnol 47:107-116

Pensa M, Jalkanen R, Liblik V (2007) Variation in Scots pine needle longevity and nutrient conservation in different habitats and latitudes. Can J For Res 37:1599-1604

Piotrowicz R, Kraska M, Klimaszyk P, Szyper H, Joniak T (2006) Vegetation richness and nutrient loads in 16 lakes of Drawieński National Park. Pol J Environ Stud 15:467-478

Pote DH, Daniel TC, Nichols DJ, Sharpley AN, Moore PA, Miller DM, Edwards DR (1999) Relationship between phosphorus levels in three ultisols and phosphorus concentrations in runoff. J Environ Quality 28:171-175

Ramm K, Scheps V (1997) Phosphorus balance of polytrophic shallow lake with the consideration of phosphorus release. Hydrobiologia 342(343):43-53

Reich PB, Oleksyn J, Modrzyński J, Mroziński P, Hobbie SE, Eissenstat DE, Chorover J, Chadwick OA, Hale C, Tjoelken MG (2005) Linking litter calcium, earthworms and soil properties: common garden test with 14 tree species. Ecol Lett 8:811-818

Renman G (1993) Frost formation in the ecotonal zone and its role for release of nutrients. Hydrobiologia 251:65-72

Rorke BB (2000) Soil erodibility and processes of water erosion on hillslope. Geomorphology 32:385-415
Rzymski P, Niedzielski P, Klimaszyk P, Poniedziałek B (2014) Bioaccumulation of selected metals in bivalves (Unionidae) and Phragmites australis inhabiting a municipal water reservoir. Environ Monit Assess 186:3199-3212

Schulze IM, Bolte A, Schmidt W, Eichhorn J (2009) Phytomass, litter and net primary production of herbaceous layer. In: Brumme R, Khanna PK (eds) Functioning and management of European beech ecosystems. Springer-Verlag, Berlin, pp 155-181

Shigaki F, Sharpley A, Prochnow LI (2007) Rainfall intensity and phosphorus source effects on phosphorus transport in surface runoff from soil trays. Sci Total Environ 373:334-343

Sickman JO, Leydecker A, Chang CCY, Kendall C, Melack JM, Lucero DM, Schimel J (2003) Mechanisms underlying export of $\mathrm{N}$ from high-elevation catchments during seasonal transitions. Biogeochemistry 64:1-24

Steinberg CEW (2003) Ecology of humic substances in freshwaters. Springer, Berlin

Strobel BW, Hansen HCB, Borggaard OK, Andersen MK, RaulundRasmussen K (2001) Composition and reactivity of DOC in forest floor soil solutions in relation to tree species and soil type. Biogeochemistry 56:1-26

Sulkava P, Huhta V (2003) Effects of hard frost and freeze-thaw cycles on decomposer communities and $\mathrm{N}$ mineralisation in boreal forest soil. Appl Soil Ecol 22:225-239

Vesterdal L (1999) Influence of soil type on mass loss and nutrient release from decomposing foliage litter of beech and Norway spruce. Can J Forest Res 29:95-105

Vuornenmaa J, Rekolainen S, Lepisto A, Kenttamies K, Kaupilla P (2002) Losses of nitrogen and phosphorus from agricultural and forest areas in Finland during the 1980s and 1990s. Environ Monit Assess 76:213-248

Woś A (1994) The Wielkopolska Lowland climate. Wydawnictwo Naukowe UAM, Poznań (in Polish)

Zieliński P, Górniak A, Choroszewska K (1999) Changes in water quality induced by the decomposition of plant detritus. Acta Hydrobiol 41:119-126 